\title{
Can Denture Wearing Increase the Nutritional Status in Pre- Elderly and Elderly Patients?
}

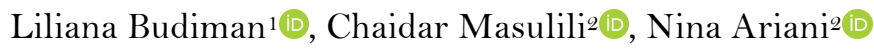

${ }^{1}$ Prosthodontics Residency Program, Faculty of Dentistry, University of Indonesia, Jakarta, Indonesia.

${ }^{2}$ Department of Prosthodontics Faculty of Dentistry, University of Indonesia, Jakarta, Indonesia.

Author to whom correspondence should be addressed: Nina Ariani, Department of Prosthodontics, Faculty of Dentistry, Universitas Indonesia, Jalan Salemba Raya No.4, Jakarta Pusat, Jakarta 10430, Indonesia. Phone: +62213151216. E-mail: nina.arianio2@ui.ac.id.

Academic Editor: Alessandro Leite Cavalcanti

Received: 12 March 2020 / Accepted: 23 June 2020 / Published: 07 July 2020

How to cite this article: Budiman L, Masulili C, Ariani N. Can denture wearing increase the nutritional status in pre-
elderly and elderly patients? Pesqui Bras Odontopediatria Clín Integr. 2020;
https://doi.org/10.1590/pboci.2020.128

\begin{abstract}
Objective: To investigate the relationships among tooth loss, denture wearing, nutrition intake, and nutritional status. Material and Methods: This observational cohort study was conducted on 26 patients ( $\geq 45$ years old) at the Faculty of Dentistry, Universitas Indonesia. Tooth loss was classified according to the Eichner Index. The Semi-quantitative Food Frequency Questionnaire was used to measure nutritional intake (kcal). Mini Nutritional Assessment Short Form (MNA-SF) and Handgrip Strength (HGS) assessments were employed to measure the nutritional status at baseline (before denture insertion), 1, 2, 3 , 6, 9, and 12 months after denture use. Results: Significant differences in nutritional intake $(\mathrm{p}<0.05)$ between the Eichner B and C groups were noted at 3, 6, 9, and 12 months after using dentures. Significant increases in nutritional intake were noted after wearing the dentures $(\mathrm{p}<0.05)$ when compared with the baseline values. The nutritional status was considered normal in $65.4 \%$ of the patients at 12 months and $38.5 \%$ at baseline. Furthermore, the nutritional status 1, 2, 3, 6, 9, and 12 months after wearing denture was significantly improved compared with the baseline values $(\mathrm{p}<0.05)$. Significant differences in HGS $(\mathrm{p}<0.05)$ were observed between the Eichner $\mathrm{B}$ and $\mathrm{C}$ groups at 6, 9, and 12 months after using the denture. However, no significant differences in HGS were noted before and after wearing the denture $(\mathrm{p}<0.05)$. Conclusion: Denture wearing can improve the nutritional intake and status of pre-elderly and elderly patients.
\end{abstract}

Keywords: Mouth, Edentulous; Jaw, Edentulous; Dentures; Tooth Loss; Nutritional Status. 


\section{Introduction}

The elderly population is predicted to increase rapidly worldwide, including developing countries like Indonesia, in the future. Based on Indonesia's population projection data, there were 23.66 million elderly people in Indonesia (9.03\%) in 2017, and this number is expected to rapidly increase to 27.08 million in 2020 and 48.19 million in $2035[1]$.

Several changes that occur in the elderly must be taken into consideration because they can affect the nutritional needs [2]. Elderly people are more susceptible to caries and periodontal disease, both of which cause tooth loss [3]. This may lead to discomfort during eating and limit the types of food consumed [4]. In addition, the elderly experience metabolic and psychological changes, which may cause systemic diseases and increased consumption of medications that could restrict the amount and type of food consumed [ 2 ]. There is no single type of food that can provide complete nutrition; therefore, a diverse food pattern is required elderly to meet the nutritional needs of the elderly $[5,6]$.

Not all people with tooth loss want to replace the missing teeth. The levels of education and awareness affect the demand for dentures [7]. Furthermore, several factors affect the appetite of the elderly, one of which is the denture's fit. Thirty-three percent of denture wearers complain that the denture does not fit and is not used for eating [8]. The elderly who often avoid certain types of food are usually denture wearers with dentures that do not fit; as a result, they usually have a lower nutritional status [9]. It is known that users of ill-fitting dentures lack 19 nutrients compared with those with complete dentition [8]. Most of the lost nutrients come from hard foods such as meat, vegetables, fruits (apples and carrots) and beans [8].

Many methods can be used to measure nutritional status. The use of several methods can provide a more comprehensive result. Clinical examinations of the hair, nails, and skin can indicate the presence of certain nutritional deficiencies. In addition, anthropometric measurements such as the body mass index (BMI), blood tests (serum or plasma), and urine, as well as saliva tests can be used to measure the nutritional status. Nutrition intake can be assessed from the type and amount of food eaten using the $24 \mathrm{~h}$ and repeat $24 \mathrm{~h}$ recalls the Food Frequency Questionnaire (FFQ), and the dietary history [4,10]. Mini Nutritional Assessment (MNA) is another widely used method comprising questionnaires validated more than 20 years ago to screen the nutritional status and help identify the presence of risk of malnutrition [11,12]. Furthermore, assessment of the Handgrip Strength (HGS) is a simple, reliable, inexpensive, and easy-to-perform method and the results may be more accurate than BMI measurements alone [13].

The relationships among tooth loss, use of dentures, and nutrition remain controversial. One study reported no relationships among these factors [14] whereas, other studies have shown an association between nutritional status and the use of dentures $[15,16]$. In the current study, the effect of the number of teeth lost and the duration of denture wearing on the nutritional status of the elderly was evaluated. The results of this study were expected to provide information about the factors that influence the nutritional status of the elderly population.

\section{Material and Methods}

Study Design and Sample

A total of 26 patients at the dental hospital provided informed consent to participate in the study. The inclusion criteria were healthy patients aged 45 and above, ability to communicate well and answer the questionnaires without the help of others, not senile, and willing to be included in the study. 


\section{Data Collection}

One investigator (LB) performed all the assessments for tooth loss before denture insertion (baseline), and the nutritional intake, nutritional status, and Handgrip Strength (HGS) at baseline, 1, 2, 3, 6, 9, and 12 months after wearing the denture. All the dentures were fabricated at the Faculty of Dentistry, Universitas Indonesia.

Tooth loss was classified using the Eichner Index, a classification based on the presence of occlusal contacts in the posterior area with regard to the masticatory ability. Based on this index, tooth loss was classified into three main categories [17]: Category A (four occlusal contact support areas), Category B (1-3 support zones or occlusal contacts anteriorly), and Category $\mathrm{C}$ (no occlusal contacts on the remaining teeth).

The semi-quantitative FFQ was used to assess the nutritional intake from the type and amount of food consumed; it relies on the memory of the subject and, if needed, help from nurses or people who take care of the subject [10]. Nutrient intake or the amount of total energy (kcal) consumed can be calculated from the portion sizes of the various types of foods consumed by the individual [18-20].

The MNA-Short Form (MNA-SF) questionnaire is widely used to screen the nutritional status of elderly people and does not need to be performed by nutritionists or doctors. Filling out the MNA questionnaire takes about $10-15 \mathrm{~min}$. A total score of $0-7$ indicates malnutrition, 8-11 indicates a risk of malnutrition, and 12-14 indicates normal nutritional status [11,12].

An assessment of the HGS was used to determine muscle strength, which is directly related to one's nutritional condition [13]. Many types of dynamometers can be used to measure muscle strength [18,21]. The Takei 5401 dynamometer (Takei Scientific Instrument Co LTD, Niigata Japan) was used in the present study. HGS can be used to measure the risk of malnutrition that cannot be seen during a clinical examination. Generally, this method is not used alone but in conjunction with other methods of measurement [13].

\section{Data Analysis}

Data were analyzed using SPSS version 22.0 software (SPSS, Inc., Chicago, IL, USA). Differences in nutritional intake (kcal) based on tooth loss (Eichner B vs. Eichner C group) were analyzed using the Mann Whitney $U$ test. Repeated analysis of variance (ANOVA) was employed to analyze the mean nutritional intake (FFQ) and HGS before using dentures and 1, 2, 3, 6, 9, and 12 months after wearing the dentures. The Friedman test was used to measure differences in nutritional status (MNA-SF) before and 1, 2, 3, 6, 9, and 12 months after wearing dentures.

\section{Ethical Considerations}

This study was approved by the ethical committee of the Faculty of Dentistry, Universitas Indonesia (No. 34/Ethical Approval/FKGUI/V/2018).

\section{Results}

Ten of the 26 patients in this study (38.5\%) were categorized into the Eichner B group and 16 (61.5\%) into the Eichner $\mathrm{C}$ group. The proportion of partial and complete denture users was almost balanced, with 12 patients wearing partial dentures $(46.2 \%)$ and $14(53.8 \%)$ wearing complete dentures. The number of male patients $(17 / 65.4 \%)$ was higher than that of the female patients $(9 / 34.6 \%)$. Three patients $(11.5 \%)$ did not complete elementary school, two (7.7\%) graduated from elementary school, six (23.1\%) from junior high school, seven (26.9\%) from high school, and eight (30.8\%) from a university. For the socio-economic data 
(income in Indonesian Rupiah/IDR), six patients (23\%) belonged to quintile 1 (income $\leq$ IDR. 658,037), four $(15.4 \%)$ to quintile 2 (IDR. 658,037 - IDR. 809,152), 7 (27\%) to quintile 3 (IDR. 809,052 - IDR. 1,000,000), 5 $(19.2 \%)$ to quintile 4 (IDR. $1,000,000$ - IDR. $1,189,207)$, and $4(15.4 \%)$ to quintile 5 (> IDR. 1,189,207).

There were significant differences in nutrient intake $(\mathrm{p}<0.05)$ between the Eichner $\mathrm{B}$ and $\mathrm{C}$ groups at 3, 6, 9, and 12 months after wearing the dentures (Table 1).

Table 1. Differences in nutritional intake (kcal) based on tooth loss.

\begin{tabular}{lccc}
\hline Evaluation & Eichner B & Eichner C & p-value \\
\hline Baseline & $1,296 \pm 144$ & $1,384 \pm 238$ & 0.309 \\
1 Month & $1,561 \pm 125$ & $1,526 \pm 182$ & 0.595 \\
2 Months & $1,688 \pm 109$ & $1,558 \pm 198$ & 0.071 \\
3 Months & $1,808(1,414-1,891)$ & $1,671(1,143-1,899)$ & $0.007^{*}$ \\
6 Months & $1,816(1,389-1,925)$ & $1,712(1,098-1,915)$ & $0.006^{*}$ \\
9 Months & $1,799(1,241-1,925)$ & $1,679(1,191-1,925)$ & $0.005^{*}$ \\
12 Months & $1,758 \pm 163$ & $1,518 \pm 211$ & $0.007^{*}$ \\
*Statistically Significant. & & &
\end{tabular}

When all the subjects were grouped together, repeated Anova showed a significant differences in mean nutritional intake between baseline $(1,351 \pm 208 \mathrm{kcal})$ compared to 1 month $(1,540 \pm 161 \mathrm{kcal}), 2$ months $(1,608 \pm 179 \mathrm{kcal}), 3$ months (1,613 $\pm 233 \mathrm{kcal}), 6$ months (1,626 $\pm 247 \mathrm{kcal}), 9$ months $(1,612 \pm 232 \mathrm{kcal})$, and 12 months $(1,611 \pm 224 \mathrm{kcal})$ after using dentures In addition, significant differences also were noted at 1 month $(1,540 \pm 161 \mathrm{kcal})$ compared with 2 months $(1,608 \pm 179 \mathrm{kcal}), 3$ months $(1,613 \pm 233 \mathrm{kcal}), 6$ months $(1,626 \pm 247 \mathrm{kcal}), 9$ months $(1,612 \pm 232 \mathrm{kcal})$ after wearing the denture (Table 2$)$.

Table 2. Differences in nutrition intake before, 1, 2, 3, 6, 9, and 12 months after wearing the dentures.

\begin{tabular}{lccccccc}
\hline Evaluation & Baseline & $\mathbf{1}$ Month & $\mathbf{2}$ Months & $\mathbf{3}$ Months & $\mathbf{6}$ Months & $\mathbf{9}$ Months & $\mathbf{1 2}$ Months \\
\hline Baseline & - & $0.001^{*}$ & $0.001^{*}$ & $0.001^{*}$ & $0.001^{*}$ & $0.001^{*}$ & $0.001^{*}$ \\
1 Month & - & - & $0.007^{*}$ & $0.021^{*}$ & $0.013^{*}$ & $0.027^{*}$ & 0.051 \\
2 Months & - & - & - & 0.819 & 0.495 & 0.874 & 0.909 \\
3 Months & - & - & - & - & 0.325 & 0.957 & 0.941 \\
6 Months & - & - & - & - & - & 0.412 & 0.442 \\
9 Months & - & - & - & - & - & - & 0.969 \\
12 Months & - & - & - & - & - & - & - \\
\hline
\end{tabular}

*Statistically Significant.

Nutritional status was determined using the MNA-SF questionnaire. Malnutrition was found at baseline in only two patients (7.7\%). The highest number of patients with risk of malnutrition was also found at baseline $(53.8 \%)$ (Table 3$)$.

Table 3. Nutritional Status Before and After Wearing Dentures.

\begin{tabular}{lccccccc}
\hline Nutritional Status & Baseline & 1 Month & 2 Months & 3 Months & 6 Months & 9 Months & 12 Months \\
& $\mathrm{N}(\%)$ & $\mathrm{N}(\%)$ & $\mathrm{N}(\%)$ & $\mathrm{N}(\%)$ & $\mathrm{N}(\%)$ & $\mathrm{N}(\%)$ & $\mathrm{N}(\%)$ \\
\hline Malnutrition & $2(7.7)$ & $\mathrm{O}(0.0)$ & $\mathrm{O}(0.0)$ & $\mathrm{O}(0.0)$ & $\mathrm{O}(0.0)$ & $\mathrm{O}(0.0)$ & $\mathrm{O}(0.0)$ \\
Risk of Malnutrition & $14(53.8)$ & $11(42.5)$ & $9(34.6)$ & $10(38.5)$ & $9(34.6)$ & $9(34.6)$ & $9(34.6)$ \\
Normal & $10(38.5)$ & $15(57.7)$ & $17(65.4)$ & $16(61.5)$ & $17(65.4)$ & $17(65.4)$ & $17(65.4)$ \\
\hline
\end{tabular}

The Friedman test showed a significant difference in nutritional status at baseline compared to 1, 2, 3, 6,9 , and 12 months after wearing a denture (Table 4). 
Table 4. Differences in nutrition status before, 1, 2, 3, 6, 9, and 12 months after wearing dentures.

\begin{tabular}{|c|c|c|c|c|c|c|c|}
\hline Evaluation & Baseline & 1 Month & 2 Months & 3 Months & 6 Months & 9 Months & 12 Months \\
\hline Baseline & & $0.005^{*}$ & *0.001* & $0.002^{*}$ & $0.001 *$ & $0.001^{*}$ & $0.001 *$ \\
\hline 1 Months & $0.005^{*}$ & - & 0.542 & 0.822 & 0.542 & 0.248 & 0.178 \\
\hline 2 Months & $0.001 *$ & - & - & 0.700 & 0.100 & 0.585 & 0.460 \\
\hline 3 Months & $0.002^{*}$ & - & - & - & 0.700 & 0.352 & 0.261 \\
\hline 6 Months & $0.001 *$ & - & - & - & - & 0.585 & 0.460 \\
\hline 9 Months & $0.001 *$ & - & - & - & - & - & 0.847 \\
\hline 12 Months & $0.001 *$ & - & - & - & - & - & - \\
\hline
\end{tabular}

*Statistically Significant.

Results of the Independent T-test showed significant differences in HGS $(\mathrm{p}<0.05)$ between the Eichner group B and C groups at 6, 9, and 12 months after using the dentures (Table 5).

Table 5. Differences in HGS (lbs.) between the Eichner B and C groups.

\begin{tabular}{cccc}
\hline Evaluation & Eichner B & Eichner C & p-value \\
\hline Baseline & $135 \pm 20$ & $119 \pm 18$ & 0.053 \\
1 Months & $133 \pm 18$ & $120 \pm 18$ & 0.086 \\
2 Months & $135 \pm 18$ & $120 \pm 19$ & 0.068 \\
3 Months & $133 \pm 16$ & $120 \pm 16$ & 0.053 \\
6 Months & $137 \pm 17$ & $120 \pm 17$ & $0.025^{*}$ \\
9 Months & $136 \pm 20$ & $120 \pm 17$ & $0.037^{*}$ \\
12 Months & $138 \pm 21$ & $120 \pm 17$ & $0.026^{*}$ \\
\hline *Statistically Significant & & &
\end{tabular}

*Statistically Significant.

Repeated ANOVA revealed no significant differences in mean HGS values before wearing dentures (125 \pm 20 lbs.) and 1 (125 \pm 19 lbs.), 2 (126 \pm 20 lbs.), 3 (125 \pm 17 lbs.), 6 (126 \pm 18 lbs.), 9 (126 \pm 19 lbs.), and 12 (127 \pm 20 lbs.) after wearing the dentures

\section{Discussion}

This study aimed to investigate the relationships between tooth loss, denture wear, and nutritional status in the elderly population. The mean FFQ values increased with the increase in the duration of denture wearing among the patients; however, no significant changes were observed after two months. This may be due to adaption to the denture. According to the American Dietetic Association, malnutrition due to inadequate intake of protein and/or energy over prolonged periods of time results in loss of fat stores and/or muscle wasting [19].

According to the Regulation of the Ministry of Health of the Republic of Indonesia (No. 28) in the year 2019, the nutritional adequacy figures in males are as follows: 30-49 years old, $2550 \mathrm{kcal}$; 50-64 years old, $2150 \mathrm{kcal}$; $65-80$ years old, $1800 \mathrm{kcal}$, and >80 years old, $1600 \mathrm{kcal}$. The corresponding values for females aged 30-49, 50-64, 65-80, and >80 years are 2150, 1800, 1550, and $1400 \mathrm{kcal}$, respectively [20]. Even though the mean of FFQ for both men and women has increased, mostly, it is still below the nutrition adequacy figures recommended by the Ministry of Health of the Republic of Indonesia.

Significant differences in nutritional status (MNA-SF) were observed at baseline when compared with $1,2,3,6,9$, and 12 months after wearing the denture. This finding is in line with that reported previously $[15,16]$.

The highest number of patients with risk for malnutrition was found at baseline (14 patients; 53.8\%). Six months after wearing the denture and thereafter, this number decreased to nine patients $(34.6 \%)$. The 
number of patients with normal nutritional status increased one month after wearing the denture; at 12 months, 17 patients (65.4\%) presented with normal nutritional status. Many factors are known to determine the nutritional status of an individual, and wearing a denture alone cannot guarantee that a normal nutritional status will be achieved.

The handgrip method has been used to assess malnutrition, which has been correlated with a decrease in muscle strength and overall functional status [21]. Physiologically, malnutrition results in decreased wholebody protein levels and body cell mass; specifically, protein synthesis decreases when the proteolytic mechanisms are stimulated. A decrease in mitochondrial complex activities also contributes to reduced muscle functioning and impaired free-energy change. Overall, these processes result in the degeneration of the muscle mass. Hence, a decrease in muscle strength has been strongly associated with loss of functional status, and HGS is proposed as an objective surrogate marker for detecting malnutrition. HGS has been validated as a rapid, cost-effective, and reliable tool for diagnosing patients with malnutrition [21] compared to other muscle-strengthening exercises such as hip flexion strength. The handgrip is positively correlated with both body cell mass and BMI [21]. The results of the repeated Anova test for inter-group comparisons (before and $1,2,3,6,9$, and 12 months after denture insertion) were not significantly different.

The limitation of this study is the number of samples that have uneven distribution among the variables studied. In addition, filling the same FFQ questionnaire and repeated for seven times can lead to bias because respondents are bored with the same questions every month and still remember the old eating patterns. Another limitation is the reading of the results on the handgrip measurement is still adjusted to the dynamometer used in this study using the Takei 5401 Handgrip Dynamometer (Takei Scientific Instrument Co. LTD, Niigata Japan), with the classification of results based on sex. Whereas in this study, there was an imbalance in the number of participants based on sex, which might lead to bias.

\section{Conclusion}

The results of this study indicate an improvement in the nutritional intake and status of the elderly patients who received replacements for their missing teeth.

\section{Authors' Contributions}

\begin{tabular}{|c|c|c|c|}
\hline LB & (iD) $0000-0002-5952-3936$ & $\begin{array}{l}\text { Conceptualization, Methodology, Investigation, Formal } \\
\text { Original Draft Preparation. }\end{array}$ & Analysis and Writing - \\
\hline $\mathrm{CM}$ & (iD) $0000-0003-3641-5358$ & $\begin{array}{l}\text { Conceptualization, Methodology, Formal Analysis and } \\
\text { Editing. }\end{array}$ & Writing - Review and \\
\hline NA & (iD) $0000-0002-3968-7052$ & $\begin{array}{l}\text { Conceptualization, Methodology, Formal Analysis and } \\
\text { Editing. }\end{array}$ & Writing - Review and \\
\hline
\end{tabular}

\section{Financial Support}

Universitas Indonesia Research Grant (Hibah PITTA A 2019), Grant No. NKB-0415/UN2.R3.1/HKP.05.00/2019.

\section{Conflict of Interest}

The authors declare no conflicts of interest.

\section{Acknowledgments}

The authors would like to thank Dr. Saraventi for her assistance with the statistics used in this article. 


\section{References}

[1] Kementrian Kesehatan Republik Indonesia. Analisis Lansia di Indonesia. Jakarta : Pusat Data dan Informasi. 2017:116. [In Indonesian].

[2] Drewnowski A, Evans WJ. Nutrition, physical activity, and quality of life in older adults: Summary. J Gerontol A Biol Sci Med Sci 2001; 56(Spec No 2):89-94. https://doi.org/10.1093/gerona/56.suppl_2.89

[3] Covit C. Geriatric dentistry. J Dent Que 1984; 21:15-8.

[4] Kementrian Kesehatan Republik Indonesia. Pedoman Pelayanan Gizi Lanjut Usia. Jakarta: Direktorat Jenderal Bina Gizi dan Kesehatan Ibu dan Anak. 2012. [In Indonesian].

[5] Wardhana GS, Baehaqi M, Amalina R. Pengaruh kehilangan gigi posterior terhadap kualitas hidup individu lanjut usia studi terhadap individu lanjut usia di unit rehabilitasi sosial pucang gading dan Panti Wredha Harapan Ibu Semarang. Odonto Dent J 2015; 2(1):40-5. [In Indonesian].

[6] Islamiyah, Jafar N, Hadju V. Status Gizi dan Kualitas Hidup Manusia Lanjut Usia yang Masih Bekerja. (Pasca Sarjana Bagian Gizi Kesehatan Masyarakat). Makasar: Fakultas Kesehatan Masyarakat, Universitas Hasanuddin; 2013. [In Indonesian].

[7] Arigbede AO, Taiwo JO. Pattern of demand for removable acrylic partial denture (RPD) in the city of Port Harcourt, Nigeria. Nig Heal J 2011; $11(2): 47-50$.

[8] Gellar MC, Alter D. The impact of dentures on the nutritional health of the elderly. J Aging Res Clin Pract 2015; $4(1): 50-3$.

[9] Wallace S, Samietz S, Abbas M, McKenna G, Woodside JV, Schimmel M. Impact of prosthodontic rehabilitation on the masticatory performance of partially dentate older patients: can it predict nutritional state? Results from a RCT. J Dent 2018; 68:66-71. https://doi.org/10.1016/j.jdent.2017.11.003

[10] Moynihan P, Thomason M, Walls A, Gray-Donald K, Morais JA, Ghanem H, et al. researching the impact of oral health on diet and nutritional status: methodological issues. J Dent 2009; 37(4):237-49. https://doi.org/10.1016/j.jdent.2008.12.003

[11] Kshetrimayum N, Reddy CVK, Siddhana S, Manjunath M, Rudraswamy S, Sulavai S. Oral health-related quality of life and nutritional status of institutionalized elderly population aged 60 years and above in Mysore City, India. Gerodontology 2013; 30(2):119-25. https://doi.org/10.1111/j.1741-2358.2012.00651.x

[12] Kaiser MJ, Bauer JM, Ramsch C, Uter W, Guigoz Y, Cederholm T, et al. Validation of the Mini Nutritional Assessment short-form $\left(\mathrm{MNA}^{\circledR}-\mathrm{SF}\right)$ : a practical tool for identification of nutritional status. J Nutr Heal Aging 2009; 13(9):782-8. https://doi.org/10.1007/s 12603-009-02 14-7

[13] Silveira TMG, Sousa JB, Stringhini MLF, Freitas ATVS, Melo PG. Nutritional assessment and handgrip strength of candidates for surgery of the gastrointestinal tract. Arq Bras Cir Dig 2014; 27(2):104-8. https://doi.org/10.1590/s0102-67202014000200005

[14] Felicita M, Koesmaningati H, Dewi RS. Relation between tooth loss and denture wearing toward nutritional status. J Int Dent Med Res 2016; 9(Special Issue):317-21.

[15] McKenna G, Allen PF, Flynn A, O’Mahony D, DaMata C, Cronin M, et al. Impact of tooth replacement strategies on the nutritional status of partially-dentate elders. Gerodontology 2012; 29(2):e883-90. https://doi.org/10.1111/j.1741-2358.2011.00579.x

[16] Yoshida M, Suzuki R, Kikutani T. Nutrition and oral status in elderly people. Jpn Dent Sci Rev 2014; 50(1):9-14. https://doi.org/10.1016/j.jdsr.2013.09.001

[17] Kosaka T, Ono T, Kida M, Kikui M, Yamamoto M, Yasui S, et al. A multifactorial model of masticatory performance: The Suita study. J Oral Rehabil 2016; 43(5):340-7. https://doi.org/10.1111/joor.12371

[18] Collins N, Friedrich L. Nutrition 411: using laboratory data to evaluate nutritional status. Ostomy Wound Manag $2010 ; 56(3): 14-6$.

[19] Kementrian Kesehatan Republik Indonesia. Indonesia. Peraturan Menteri Kesehatan Republik No 28 Tahun 2019 Tentang Angka Kecukupan Gizi. Jakarta; 2019. p. 1-33. [In Indonesian].

[20] Bharadwaj S, Ginoya S, Tandon P, Gohel TD, Guirguis J, Vallabh H, et al. Malnutrition: laboratory markers vs nutritional assessment. Gastroenterol Rep 2016; 4(4):272-280. https://doi.org/10.1093/gastro/gow013

[21] National Health and Nutrition Examination Survey. Muscle Strength Procedures Manual. United States: Department of Health and Human Services. Available from: https://wwwn.cdc.gov/nchs/data/nhanes/20112012/manuals/Muscle_Strength_Proc_Manual.pdf. [Accessed on February 14, 2020]. 